\title{
Influence of microbial additive on microbial populations, ensiling characteristics, and spoilage loss of delayed sealing silage of Napier grass
}

\author{
Yimin Cai ${ }^{1, a, *}$, Zhumei Du ${ }^{2, a}$, Seishi Yamasaki ${ }^{1}$, Damiao Nguluve ${ }^{3}$, Benedito Tinga ${ }^{3}$, \\ Felicidade Macome ${ }^{3}$, and Tetsuji Oya ${ }^{1}$
}

\section{* Corresponding Author: Yimin Cai Tel: +86-298386365, Fax: +86-298386653, E-mail: cai@affrc.go.jp}

1 Japan International Research Center for Agricultural Sciences (JIRCAS), Tsukuba, Ibaraki 305-8686, Japan 2 Department of Grassland Science, China Agricultural University, Beijing 100193, China

${ }^{3}$ Agricultural Research Institute of Mozambique, Matola 999068, Mozambique

a They are co-first authors and contributed equally to this article.

ORCID

Yimin Cai

https://orcid.org/0000-0003-2650-5210

Zhumei Du

https://orcid.org/0000-0003-1288-5208

Seishi Yamasaki

https://orcid.org/0000-0003-4376-7642

Damiao Nguluve

https://orcid.org/0000-0001-6391-7295

Benedito Tinga

https://orcid.org/0000-0002-3008-6795

Felicidade Macome

https://orcid.org/0000-0002-0413-4335

Tetsuji Oya

https://orcid.org/0000-0002-7839-7517

Submitted Jun 6, 2019; Revised Jul 23, 2019; Accepted Aug 19, 2019
Objective: To measure whether a microbial additive could effectively improve the fermentation quality of delayed-sealing (DS) silage, we studied the effects of inoculants of lactic acid bacteria (LAB) and cellulase enzyme on microbial populations, ensiling characteristics, and spoilage loss of DS silage of Napier grass in Africa.

Methods: Quick-sealing (QS) and DS silages were prepared with and without LAB (Lactobacillus plantarum) inoculant, cellulase enzymes, and their combination. The QS material was directly chopped and packed into a bunker silo. The DS material was packed into the silo with a delay of $24 \mathrm{~h}$ from harvest.

Results: In the QS silage, LAB was dominant in the microbial population and produced large amounts of lactic acid. When the silage was treated with LAB and cellulase, the fermentation quality was improved. In the DS silage, aerobic bacteria and yeasts were the dominant microbes and all the silages were of poor quality. The yeast and mold counts in the DS silage were high, and they increased rapidly during aerobic exposure. As a result, the DS silages spoiled faster than the QS silages upon aerobic exposure.

Conclusion: DS results in poor silage fermentation and aerobic deterioration. The microbial additive improved QS silage fermentation but was not effective for DS silage.

Keywords: Aerobic Deterioration; Delayed Sealing; Microbial Additive; Napier Grass Silage; Quick Sealing

\section{INTRODUCTION}

Napier grass (Pennisetum purpureum Schumach) is the major feed in dairy cattle production systems in the tropics, including Africa [1,2]. Generally, Napier grass is widely planted because of its high biomass yield and its adaptations to survive under a wide range of soil types, fertility levels, and weather conditions [3]. The major constraint on dairying in the tropics is the shortage of feed for animal production, in terms of both quality and quantity, particularly in the dry season [4]. In Africa, the main sources of roughage for cattle are Napier grass, native grasses, and agricultural byproducts. When cattle are fed low-quality roughage, milk and meat production decrease $[5,6]$. Therefore, efficient utilization of local feed resources is important for promoting animal husbandry. The aim of ensiling, which is a traditional conservation method for fresh forage crops and grasses, is ensuring year-round availability of nutritious and palatable feed for livestock. To establish a forage production system to address the problem of animal feed shortages in the dry season, large-scale silage preparation technology using tropical grasses or forages has been developed and is used for local animal production. 
Frequently, silage producers must weigh the consequences of delaying forage conservation against the risks of damage due to machine malfunction or natural rainfall events before harvest. The decision to delay conservation of forage in an attempt to avoid unstable weather is not without cost because it generally results in a more mature forage crop coupled with the associated reductions in nutritive value, which are widely recognized and understood [7]. Furthermore, damage to wilting forage crops or delayed sealing (DS) due to unexpected weather events or machine malfunction, which has been described as more damaging to nutritive value than delaying the harvest, are often unavoidable in the tropics [8]. Generally, DS and aerobic exposure seriously influence silage fermentation. When sealing is delayed for a long time, aerobic microbes may grow vigorously, and the substrates may be oxidized, resulting in poor fermentation during future ensiling [9]. In addition, when the silo is opened at feeding time, aerobic conditions prevail, and the silage is subject to the growth of aerobic microbes and becomes potentially unstable [10].

In the harvest season in African countries, silage preparation can be interrupted due to sudden rainfall and machine malfunction, and the grass and forage crop after harvest may sometimes experience aerobic exposure and DS. Hence, in animal feed production, it has become important to develop a means to improve silage fermentation with DS materials and inhibit aerobic deterioration. However, little information regarding silage fermentation and aerobic deterioration using DS forages in Africa is available. In addition, the question of whether microbial inoculants can improve DS silage fermentation and aerobic stability remains unclear. We examine the effects of inoculants of lactic acid bacteria (LAB) and cellulase enzymes on microbial populations, ensiling characteristics, and spoilage loss of DS Napier grass silage in Mozambique.

\section{MATERIALS AND METHODS}

\section{Ensiling materials and silage preparation}

Napier grass was obtained from an experimental field at the Agricultural Research Institute of Mozambique, Matola, Mozambique in February 2018. Napier grass was harvested and chopped into 1 to $2 \mathrm{~cm}$ lengths using a mechanical chopper (92-2S, Sida Agri-Machine Co., Ltd, Luoyang, China). The bunker silages were prepared with quick-sealing (QS) and DS forages. The QS forages were packed into a bunker silo $(2 \times 4 \times 10 \mathrm{~m})$ within $10 \mathrm{~h}$ of harvesting. The DS forages were interrupted by machine malfunction and rainfall, and the packing was completed approximately $24 \mathrm{~h}$ after harvesting. A commercial inoculant, Chikuso-1 (Lactobacillus plantarum, Snow Brand Seed Co., Ltd., Sapporo, Japan) was used to prepare both silages. To compare the fermentation quality between QS and DS forages and to verify the effect of microbial additives on silage fermentation, silages were also prepared in $150-\mathrm{L}$ polyethylene drum can silos and subjected to the following treatments: control, $\mathrm{LAB}$, cellulase, and $\mathrm{LAB}+$ cellulase. The experiment was designed as a $2 \times 4$ factorial study in a completely randomized design (sealing $\times$ additive treatment) with three replicates per treatment. The LAB inoculant Chikuso- 1 and Acremonium cellulase (Acremonium cellulase, Meiji Seika Pharma Co., Ltd, Tokyo, Japan) were used as silage additives based on the guidelines of a commercial manufacturer. The inoculant strain was originally isolated from a sealing crop that could produce large amounts of lactic acid in the silage environment. Cellulase was produced from Acremonium cellulolyticus, with the main components being glucanase and pectinase; the carboxymethyl cellulase activity was $7,350 \mathrm{U} / \mathrm{g}$. The LAB was inoculated at $5 \mathrm{mg} / \mathrm{kg}$ as $1.0 \times 10^{5}$ colony-forming unit (cfu)/g on a fresh matter (FM) basis. Cellulase was added at $10 \mathrm{mg}$ blended with 20 $\mathrm{mL}_{2} \mathrm{O}$ per kg of FM. The LAB and cellulase were diluted with deionized water, and the additive solution was sprayed using an electronic sprayer (SSP-5H, Fujiwara Sangyo Co., Ltd., Miki, Japan) to add experimental treatments. Under the control treatment, silage was sprayed with the same amount of water. The bunker and drum can silos were compacted to exclude air from forages, and a density of approximately $380 \mathrm{~kg} / \mathrm{m}^{3}$ was achieved. The silos were kept at an ambient temperature of $25^{\circ} \mathrm{C}$ to $32^{\circ} \mathrm{C}$ and were opened after $60 \mathrm{~d}$ of ensiling to assess fermentation quality and perform a microbial analysis.

\section{Microbial analysis}

The counts of microorganisms in the Napier grass or silages were measured by the plate count method [11]. Samples (10 g) were blended with $90 \mathrm{~mL}$ sterilized water and serially diluted $10^{-1}$ to $10^{-8}$ in sterilized water. The numbers of LAB were measured on Lactobacilli MRS (de Man, Rogosa, and Sharpe) agar (Difco Laboratories, Detroit, MI, USA) incubated at $30^{\circ} \mathrm{C}$ for $48 \mathrm{~h}$ under anaerobic conditions (Anaerobic Pack Rectangular Jar; 2.5 liters, Mitsubushi Gas Chemical Company INC, Tokyo, Japan). For isolation of LAB, more than 10 strains on MRS agar medium were picked randomly from each sample, and a total of 35 isolates were collected, of which 28 isolates were considered to be LAB, as determined by the Gram-stain, catalase reaction and lactic acid productivity [11]. Aerobic bacteria were counted on Nutrient agar (Nissui-Seiyaku Co., Ltd, Tokyo, Japan) incubated for $48 \mathrm{~h}$ at $30^{\circ} \mathrm{C}$ under aerobic conditions. Coliform bacteria were counted on Blue Light agar (Nissui-Seiyaku, Japan) incubated at $30^{\circ} \mathrm{C}$ for $48 \mathrm{~h}$; the yeasts and molds were counted on Potato Dextrose agar (Nissui-Seiyaku, Japan) incubated for 48 to 72 $\mathrm{h}$ at $30^{\circ} \mathrm{C}$. Yeasts were distinguished from molds and bacteria by colony appearance and observation of cell morphology. Colonies were counted as viable numbers of microorganisms in cfu/g of FM. For LAB identification, each colony of LAB 
was purified twice by streaking on a MRS agar plate. The pure cultures were grown on MRS agar at $30^{\circ} \mathrm{C}$ for $24 \mathrm{~h}$, resuspended in a solution of nutrient broth (Difco, USA) and dimethyl sulfoxide at a ratio of 9:1, and stored as stock cultures in a deep freezer (MDF-U384, Sanyo Electric Co., Ltd, Osaka, Japan) at $-80^{\circ} \mathrm{C}$ until further examination. The $16 \mathrm{~S}$ rDNA sequence similarity was performed at GenBank data library by using the BLAST program as described by Cai et al [12].

\section{Chemical analysis}

Pre-ensiled Napier grass, and their silage samples were dried in a forced air oven at $70^{\circ} \mathrm{C}$ for $48 \mathrm{~h}$, and ground to pass a 1 mm mesh screen (FW 100, Taisite Instrument Co., Ltd, Tianjin, China) for chemical composition analyses. The data of chemical composition on dry matter (DM) basis were corrected for residual moisture after $3 \mathrm{~h}$ at $105^{\circ} \mathrm{C}$. The $\mathrm{DM}$, ash, crude protein (CP), and ether extract (EE) were analyzed by the methods $950.15,942.05,984.13$, and 920.39 of AOAC [13], respectively. The organic matter (OM) content was calculated as the weight loss upon ashing. The neutral detergent fiber (NDF) and acid detergent fiber (ADF) were obtained according to the method of Van Soest [14] with an ANKOM A200i fiber analyzer (ANKOM Technology, Macedon, NY, USA) and were expressed exclusive of residual ash. The nonfibrous carbohydrate (NFC) according to Hall [15]. The acid detergent lignin (ADL) analysis was subsequently performed following the procedure of Van Soest [14]. The water-soluble carbohydrate (WSC) content was measured by high-performance liquid chromatography (HPLC) method as described by Cai et al [12], and the WSC was calculated as the sum of glucose, fructose and sucrose. Lactate buffer capacity (LBC) was measured by titrating with $0.1 \mathrm{M} \mathrm{HCl}$ to reduce $\mathrm{pH}$ from initial $\mathrm{pH}$ to $\mathrm{pH} 3.0$ and then titrated to $\mathrm{pH} 6.0$ with $0.1 \mathrm{M}$ $\mathrm{NaOH}$ as described by McDonald et al [16].

\section{Fermentation analysis}

The fermentation products of silage were analyzed by using cold-water extract, a $10 \mathrm{~g}$ wet silage sample was homogenized with $90 \mathrm{~mL}$ of deionized water and kept in a refrigerator at $4^{\circ} \mathrm{C}$ for $24 \mathrm{~h}$ as described by Cai [17]. Then, the material was filtered, and the filtrate was used to measure $\mathrm{pH}$, ammonia nitrogen $\left(\mathrm{NH}_{3}-\mathrm{N}\right)$ and organic acids. The $\mathrm{pH}$ was measured using a glass electrode $\mathrm{pH}$ meter (Starter 100/B, OHAUS, Shanghai, China), the $\mathrm{NH}_{3}-\mathrm{N}$ analyzed by using steam distillation of the filtrates [17], the concentration of organic acid including lactic acid, acetic acid, propionic acid and butyric acid were measured by HPLC method [17] using Shodex RS Pak KC-811 column (Showa Denko K.K., Kawasaki, Japan), DAD detector (210 nm, SPD-20A, Shimadzu Co., Ltd, Kyoto, Japan), eluent ( $3 \mathrm{mmol} / \mathrm{L} \mathrm{HClO} 4,1.0 \mathrm{~mL} / \mathrm{min}$ ), temperature $\left(40^{\circ} \mathrm{C}\right)$.

\section{Aerobic stability measurement}

After $60 \mathrm{~d}$ of ensiling, the bunker silos from the QS and DS silages were opened, and 5,000-g silage samples were packed into 15-L laboratory plastic silos. The silos were covered loosely, but not sealed, and then placed in a laboratory for $6 \mathrm{~d}$ at $26^{\circ} \mathrm{C}$ to $30^{\circ} \mathrm{C}$. Samples from the upper surface were used to examine changes in the counts of yeast and mold, $\mathrm{pH}$, lactic acid content, and temperature at 1,3 , and $6 \mathrm{~d}$ of aerobic incubation. The temperature was measured using a thermometer (No. 7, Ishihara-Ondokei Co., Ltd., Tokyo, Japan) at 06:00, 12:00, 18:00, and 24:00 each day, and the average temperature was used to indicate the silage temperature. The spoilage loss of silage was calculated as the percentage of the weight of molds occurring in the silage to the total weight of silage on an FM basis.

\section{Statistical analysis}

Data on the microorganism population, chemical composition and fermentation quality after $60 \mathrm{~d}$ of ensiling were analyzed with a completely randomized design with a $2 \times 4$ (sealing [S] $\times$ additive $[\mathrm{A}]$ ) factorial treatment structure. The two ways analysis of variance (ANOVA) procedure of SAS version 9.1 (SAS Institute, Cary, NC, USA) was used for the analysis and the statistical model is as follows:

$$
Y_{i j k}=\mu+\alpha_{i}+\beta_{j}+\alpha \beta_{i j}+\varepsilon_{i j k}
$$

where $Y_{\mathrm{ijk}}=$ observation; $\mu$ = overall mean, $\alpha_{\mathrm{i}}=\mathrm{S}$ treatment effect ( $\mathrm{i}=$ Napier grass), $\beta_{\mathrm{j}}=\mathrm{A}$ effect $(\mathrm{j}=1$ to 4$), \alpha \beta_{\mathrm{ij}}=\mathrm{S} \times \mathrm{A}$ effect, and $\varepsilon_{\mathrm{ijk}}=$ error. The mean values were compared by Tukey's test [18].

Data of aerobic stability on the lactic acid content, $\mathrm{pH}$, temperature and counts of aerobic acid, yeast and mold after $1 \mathrm{~d}$, $3 \mathrm{~d}$, and $6 \mathrm{~d}$ of aerobic exposure were analyzed with a completely randomized design with a $2 \times 3$ (S×exposure days [D]) factorial treatment structure. The two ways ANOVA procedure of SAS version 9.1 (SAS Institute, USA) was used for the analysis.

\section{RESULTS}

The chemical composition and microbial population of Napier grass before ensiling are shown in Table 1 . The DM content of Napier grass was $29.65 \%$ for QS and $30.13 \%$ for DS. The $\mathrm{OM}, \mathrm{EE}, \mathrm{ADL}$, and NFC contents of QS and DS were similar, ranging from $85.05 \%$ to $85.72 \%, 1.25 \%$ to $1.35 \%, 5.68 \%$ to $6.11 \%$, and $9.54 \%$ to $11.46 \%$, respectively, on a DM basis. The CP, NDF, and WSC contents in QS were 5.56\%, 66.74\%, and $3.10 \%$ of DM, respectively, higher $(\mathrm{p} \leq 0.01$ or $\mathrm{p}=0.03$ ) than the corresponding values in DS. The ADF content in QS was $41.53 \%$, which was lower $(\mathrm{p}=0.02)$ than that in DS. The LBC in QS was 532.10 metabolizable energy $/ \mathrm{kg}$ on a DM 
Table 1. Chemical composition and microbial population of Napier grass before ensiling

\begin{tabular}{|c|c|c|c|c|}
\hline \multirow{2}{*}{ Items } & \multicolumn{2}{|c|}{ Napier grass } & \multirow{2}{*}{ SEM } & \multirow{2}{*}{ p-value } \\
\hline & Quick-sealing & Delayed-sealing & & \\
\hline \multicolumn{5}{|l|}{ Chemical composition } \\
\hline $\mathrm{DM}(\%)$ & $29.65 \pm 0.97$ & $30.13 \pm 1.12$ & 0.61 & 0.64 \\
\hline $\mathrm{OM}(\%$ of $\mathrm{DM})$ & $85.72 \pm 1.46$ & $85.05 \pm 1.06$ & 0.74 & 0.56 \\
\hline $\mathrm{CP}(\%$ of $\mathrm{DM})$ & $5.56 \pm 0.21$ & $5.07 \pm 0.14$ & 0.10 & 0.03 \\
\hline $\mathrm{EE}(\%$ of DM) & $1.35 \pm 0.09$ & $1.25 \pm 0.09$ & 0.05 & 0.22 \\
\hline NDF (\%of DM) & $66.74 \pm 0.80$ & $64.18 \pm 0.41$ & 0.37 & 0.01 \\
\hline ADF (\%of DM) & $41.53 \pm 1.04$ & $43.90 \pm 0.37$ & 0.45 & 0.02 \\
\hline ADL ( $\%$ of $D M)$ & $5.68 \pm 0.05$ & $6.11 \pm 0.34$ & 0.27 & 0.32 \\
\hline WSC ( $\%$ of DM) & $3.10 \pm 0.28$ & $0.94 \pm 0.33$ & 0.18 & $<0.01$ \\
\hline NFC ( $\%$ of DM) & $11.46 \pm 1.09$ & $9.54 \pm 0.64$ & 0.52 & 0.06 \\
\hline LBC (ME/kg of DM) & $532.10 \pm 12.59$ & $564.30 \pm 13.20$ & 7.45 & 0.04 \\
\hline \multicolumn{5}{|c|}{ Microbial population ( $\log _{10}$ cfu/g of FM) } \\
\hline Lactic acid bacteria & $5.42 \pm 0.45$ & $7.12 \pm 0.99$ & 0.44 & 0.05 \\
\hline Coliform bacteria & $6.55 \pm 0.55$ & $8.85 \pm 0.37$ & 0.27 & $<0.01$ \\
\hline Aerobic bacteria & $6.80 \pm 0.22$ & $9.01 \pm 0.28$ & 0.15 & $<0.01$ \\
\hline Yeast & $4.19 \pm 0.39$ & $6.19 \pm 0.24$ & 0.19 & $<0.01$ \\
\hline Mold & $2.78 \pm 0.71$ & $5.90 \pm 0.09$ & 0.29 & $<0.01$ \\
\hline
\end{tabular}

Data are means of three silage samples.

SEM, standard error of the mean; DM, dry matter; OM, organic matter; $C P$, crude protein; EE, ether extract; NDF, neutral detergent fiber; ADF, acid detergent fiber; ADL, acid detergent lignin; WSC, water-soluble carbohydrates; NFC, non-fibrous carbohydrate; LBC, lactate buffering capacity; ME, metabolizable energy; FM, fresh matter; cfu, colony-forming unit.

basis, which was lower $(\mathrm{p}=0.04)$ than that in DS. Before ensiling, the LAB counts in the QS and DS were similar, ranging from 5.42 to $7.12 \log _{10} \mathrm{cfu} / \mathrm{g}$ on a FM basis. The coliform bacterial, aerobic bacteria, yeast, and mold counts in DS were $8.85,9.01,6.19$, and $5.90 \log _{10} \mathrm{cfu} / \mathrm{g}$ of FM, respectively, and these microbes were higher than the $2 \log _{10} \mathrm{cfu} / \mathrm{g}$ of FM in QS.

The identification and physiological properties of the inoculant and representative strains from Napier grass or silage are shown in Table 2. The strain Chikuso 1 was obtained from a commercial inoculant, while the representative strains NG 5 , NG 7, and NG 12 were isolated from forage and silage. All strains were Gram-positive, catalase-negative rod or cocci, and homofermentative or heterofermentative bacteria. The strains NG 5 and NG 12 formed lactic acid as the D-isomer, strain NG 7 exclusively formed lactic acid as the L-isomer, and Chikuso 1 produced a racemic mixture of $\mathrm{D}$ - and L-lactic acid. These strains were able to grow at $15^{\circ} \mathrm{C}$ and fermented glucose, fructose, and sucrose. The strain Chikuso 1 grew at a lower $\mathrm{pH}$ condition than the others. Based on the morphological and biochemical characteristics and a $16 \mathrm{~S}$ rRNA gene sequence analysis, these isolates were identified as Lactobacillus plantarum, Weissella cibaria, Lactococcus lactis, and Leuconostoc mesenteroids, respectively.

The chemical composition of Napier grass silages is shown in Table 3. After $60 \mathrm{~d}$ of ensiling, the OM, EE, and ADL contents of the QS and DS silages were similar levels at $86.26 \%$ to $88.60 \%, 2.14 \%$ to $2.42 \%$, and $5.99 \%$ to $6.12 \%$ of DM, re- spectively. These contents in QS and DS silages did not differ markedly among the control, LAB, cellulase, and LAB+cellulase treatments. Compared to the DS silage, the QS silage had greater $(\mathrm{p}<0.05) \mathrm{CP}$ and NDF contents. The CP content of the cellulase- or $\mathrm{LAB}+$ cellulase-treated silages were higher $(\mathrm{p}<0.05)$, while the NDF and ADF contents were lower $(\mathrm{p}<$ 0.05 ) than those of the control. The CP, NDF, and ADF contents were influenced $(\mathrm{p}<0.01)$ by $\mathrm{S}$, but not the OM, EE, ADL, and NFC contents. The contents of NDF and ADF were influenced $(p=0.03)$ by $A$, but not the other chemical compositions. The interaction between $\mathrm{S}$ and $\mathrm{A}$ did not influence chemical composition.

The fermentation quality of Napier grass silage after $60 \mathrm{~d}$ of fermentation is shown in Table 4. When silage was prepared under QS conditions, the $\mathrm{pH}$, acetic acid, propionic acid, butyric acid, and $\mathrm{NH}_{3}-\mathrm{N}$ (g/kg total nitrogen, $\mathrm{TN}$ ) contents were lower $(\mathrm{p}<0.05)$, and the lactic acid content was higher $(\mathrm{p}<$ 0.05 ) in LAB-, cellulase-, and LAB+cellulase-treated silages than in the control. In contrast, when silage was prepared under DS conditions, all silages were of poor quality, with low lactic acid content $(0.14 \%$ to $0.36 \%$ of FM), a relatively high $\mathrm{pH}(>4.20)$, and high $\mathrm{NH}_{3}-\mathrm{N}$ content (116.61 to $125.77 \mathrm{~g} / \mathrm{kg}$ $\mathrm{TN})$. The LAB-, cellulase-, and LAB+cellulase-treated silages were not markedly different from the control. Compared to the DS silages, the QS silages were better preserved, had higher $(\mathrm{p}<0.05)$ lactic acid, propionic acid, and butyric acid contents, and lower $(\mathrm{p}<0.05) \mathrm{pH}$, acetic acid, and $\mathrm{NH}_{3}-\mathrm{N}$ contents. The silage fermentation was influenced ( $\mathrm{p} \leq 0.01$ or $\mathrm{p}=0.04$ ) by $\mathrm{S}$. 
Table 2. Identification and physiological properties of inoculant strain and representative strains from Napier grass or silage

\begin{tabular}{|c|c|c|c|c|}
\hline Characteristic & $\begin{array}{l}\text { Lactobacillus } \\
\text { plantarum }\end{array}$ & Weissella cibaria & Lactococcus lactlis & $\begin{array}{l}\text { Leuconostoc } \\
\text { mesenteroids }\end{array}$ \\
\hline Source & Inoculant & Material & Material & Silage \\
\hline Representative strain & Chikuso 1 & NG 5 & NG 7 & NG 12 \\
\hline \multicolumn{5}{|l|}{ LAB characteristics } \\
\hline Shape & Rod & Cocci & Cocci & Cocci \\
\hline Gram stain & + & + & + & + \\
\hline Catalase & - & - & - & - \\
\hline Fermentation type & Homo & Hetero & Homo & Hetero \\
\hline Optical form of lactate & DL & $D(-)$ & $\mathrm{L}(+)$ & $D(-)$ \\
\hline \multicolumn{5}{|l|}{ Growth at } \\
\hline $15^{\circ} \mathrm{C}$ & + & + & + & + \\
\hline $45^{\circ} \mathrm{C}$ & + & - & - & - \\
\hline \multicolumn{5}{|l|}{ Growth at } \\
\hline pH 3.0 & + & - & - & - \\
\hline pH 3.5 & + & - & - & - \\
\hline $\mathrm{pH} 4.0$ & + & - & - & - \\
\hline $\mathrm{pH} 4.5$ & + & + & & + \\
\hline pH 5.0 & + & + & + & + \\
\hline \multicolumn{5}{|l|}{ Fermentation of sugar } \\
\hline Glucose & + & + & + & + \\
\hline Fructose & + & + & + & + \\
\hline Sucrose & + & + & + & + \\
\hline Starch & w & - & - & - \\
\hline 16S rDNA sequence similarity with each type strain (\%) & 100 & 99.96 & 99.90 & 99.94 \\
\hline
\end{tabular}

$L A B$, lactic acid bacteria inoculant Chikuso-1; +, positive; -, negative; w, weakly positive; Homo, homofermentative bacteria; Hetero, heterofermentative bacteria.

The contents of acetic acid, propionic acid, and butyric acid were influenced $(\mathrm{p}<0.01$ or $\mathrm{p}=0.05)$ by $\mathrm{A}$, whereas the $\mathrm{DM}$, $\mathrm{pH}$, lactic acid, and $\mathrm{NH}_{3}-\mathrm{N}$ contents were not. The lactic acid, propionic acid, and butyric acid contents were influenced $(\mathrm{p} \leq 0.01)$ by $\mathrm{S} \times \mathrm{A}$, while the $\mathrm{DM}, \mathrm{pH}$, acetic acid, and $\mathrm{NH}_{3}-\mathrm{N}$ contents were not.

The microbial populations of Napier grass silage after 60 $\mathrm{d}$ of fermentation are shown in Table 5. In the QS silages, LAB were the dominant species, with counts ranging from 5.47 to $6.70 \log _{10} \mathrm{cfu} / \mathrm{g}$ on an FM basis. Compared with the control silage, the counts of coliform bacteria and mold in LAB-, cellulase-, and LAB+cellulase-treated silages were significantly decreased. In the additives-treated silages, coliform bacteria and mold counts were below detectable levels $\left(<10^{2}\right.$ $\mathrm{cfu} / \mathrm{g}$ on an FM basis). In the DS silage, aerobic bacteria were the dominant species, with counts ranging from 6.19 to 6.38 $\log _{10} \mathrm{cfu} / \mathrm{g}$ on an FM basis. The LAB, coliform bacteria, yeast, and mold counts were 4.64 to $6.16 \log _{10} \mathrm{cfu} / \mathrm{g}$ of FM. The microbial population in the DS silages did not differ markedly among all treatments. The microbial population $(\mathrm{p}<0.01)$ were influenced by $\mathrm{S}$, and the coliform bacteria counts were influenced $(\mathrm{p}<0.01)$ by $\mathrm{A}$ and $\mathrm{S} \times \mathrm{A}$, whereas other microorganisms were not.

Changes in lactic acid content, yeast and mold counts, $\mathrm{pH}$, and temperature during the aerobic exposure of bunker silage for 1, 3, and $6 \mathrm{~d}$ are shown in Table 6 . In the DS silages, the yeast and mold counts in all silages increased rapidly during aerobic exposure and reached values of 9.43 and 6.93 $\log _{10} \mathrm{cfu} / \mathrm{g}$ on an FM basis after $6 \mathrm{~d}$. With yeast and mold growth, a rise in $\mathrm{pH}$ and temperature and a reduction in lactic acid content were observed. In the QS silages, the yeast and mold counts, $\mathrm{pH}$, and temperature were lower $(\mathrm{p}<0.05)$, but the lactic acid was higher $(\mathrm{p}<0.05)$ than in the DS silages. The lactic acid, yeasts, molds, $\mathrm{pH}$, and temperature were influenced $(\mathrm{p}<0.01)$ by $S$ and $\mathrm{D}$. The lactic acid content, mold count, and temperature were influenced $(\mathrm{p}<0.01)$ by $\mathrm{S} \times \mathrm{D}$; the yeast count and $\mathrm{pH}$ were not influenced.

The spoilage loss of QS and DS silage prepared with drum can and bunker silos after $60 \mathrm{~d}$ of ensiling are shown in Figure 1. The spoilage losses of DS silage prepared with drum can and bunker silos were higher $(\mathrm{p}<0.05)$ than those for QS silage.

\section{DISCUSSION}

Good silage fermentation depends on the moisture, WSC concentration, and buffer capacity of the forage crops or grasses $[16,19,20]$. In this study, the WSC content of DS Napier grass was lower than that in the QS treatment. This is consistent with the results of previous studies [21] that have clearly illus- 
Table 3. Chemical composition of Napier grass silage after $60 \mathrm{~d}$ of fermentation

\begin{tabular}{|c|c|c|c|c|c|c|c|}
\hline \multirow{2}{*}{ Items } & $\mathrm{OM}$ & $\mathrm{CP}$ & $\mathrm{EE}$ & NDF & ADF & $A D L$ & NFC \\
\hline & \multicolumn{7}{|c|}{ 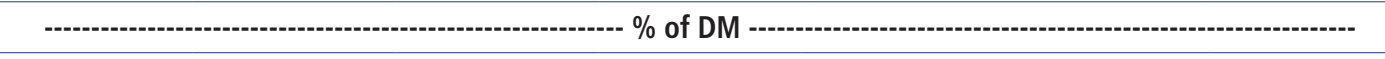 } \\
\hline \multicolumn{8}{|l|}{ Quick-sealing } \\
\hline Control & $87.07 \pm 1.05$ & $4.74 \pm 0.07^{b}$ & $2.42 \pm 0.14$ & $71.80 \pm 0.77^{\mathrm{a}}$ & $43.03 \pm 1.06^{a}$ & $5.99 \pm 0.22$ & $10.02 \pm 0.24^{b}$ \\
\hline$L A B$ & $88.54 \pm 0.86$ & $5.02 \pm 0.15^{\mathrm{ab}}$ & $2.37 \pm 0.17$ & $71.50 \pm 0.90^{\mathrm{a}}$ & $42.89 \pm 1.49^{a}$ & $6.05 \pm 0.18$ & $11.56 \pm 0.28^{\mathrm{ab}}$ \\
\hline Cellulase & $88.60 \pm 1.06$ & $5.25 \pm 0.21^{\mathrm{a}}$ & $2.26 \pm 0.24$ & $69.70 \pm 0.83^{b}$ & $40.49 \pm 1.01^{b}$ & $6.05 \pm 0.11$ & $12.51 \pm 1.28^{\mathrm{a}}$ \\
\hline LAB+cellulase & $88.27 \pm 0.56$ & $5.10 \pm 0.17^{\mathrm{a}}$ & $2.19 \pm 0.16$ & $69.40 \pm 0.85^{b}$ & $40.61 \pm 1.02^{b}$ & $6.08 \pm 0.18$ & $11.63 \pm 1.01^{\mathrm{ab}}$ \\
\hline \multicolumn{8}{|l|}{ Delayed-sealing } \\
\hline Control & $86.47 \pm 0.91$ & $4.27 \pm 0.25^{\mathrm{a}}$ & $2.26 \pm 0.21$ & $69.93 \pm 1.28^{\mathrm{a}}$ & $44.30 \pm 0.69^{a}$ & $6.03 \pm 0.19$ & $10.70 \pm 1.17^{\mathrm{a}}$ \\
\hline$L A B$ & $86.26 \pm 2.55$ & $4.17 \pm 0.16^{\mathrm{a}}$ & $2.15 \pm 0.17$ & $68.53 \pm 1.41^{\mathrm{a}}$ & $44.02 \pm 1.43^{\mathrm{a}}$ & $6.08 \pm 0.18$ & $10.97 \pm 1.14^{a}$ \\
\hline Cellulase & $87.21 \pm 1.96$ & $4.27 \pm 0.29^{\mathrm{a}}$ & $2.15 \pm 0.08$ & $68.31 \pm 1.39^{\mathrm{a}}$ & $42.67 \pm 1.58^{a}$ & $6.12 \pm 0.23$ & $11.01 \pm 1.06^{\mathrm{a}}$ \\
\hline LAB+cellulase & $87.86 \pm 1.51$ & $4.15 \pm 0.09^{\mathrm{a}}$ & $2.14 \pm 0.25$ & $68.93 \pm 1.09^{a}$ & $42.99 \pm 2.14^{\mathrm{a}}$ & $6.10 \pm 0.19$ & $11.80 \pm 1.34^{\mathrm{a}}$ \\
\hline SEM & 0.83 & 0.11 & 0.11 & 0.63 & 0.79 & 0.11 & 0.59 \\
\hline \multicolumn{8}{|l|}{ Sealing means } \\
\hline Quick & $88.12 \pm 1.01$ & $5.03 \pm 0.24^{\mathrm{a}}$ & $2.31 \pm 0.81$ & $70.60 \pm 1.32^{\mathrm{a}}$ & $41.76 \pm 1.60^{b}$ & $6.04 \pm 0.15$ & $11.43 \pm 1.17$ \\
\hline Delay & $86.95 \pm 1.70$ & $4.22 \pm 0.19^{b}$ & $2.17 \pm 0.17$ & $68.92 \pm 1.28^{b}$ & $43.50 \pm 1.50^{\mathrm{a}}$ & $6.08 \pm 0.18$ & $11.12 \pm 1.10$ \\
\hline \multicolumn{8}{|l|}{ Additive means } \\
\hline Control & $86.77 \pm 0.94$ & $4.51 \pm 0.31^{b}$ & $2.34 \pm 0.18$ & $70.86 \pm 1.39^{a}$ & $43.66 \pm 1.06^{a}$ & $6.01 \pm 0.19$ & $10.36 \pm 0.84^{b}$ \\
\hline$L A B$ & $87.40 \pm 2.11$ & $4.60 \pm 0.49^{\mathrm{ab}}$ & $2.26 \pm 0.19$ & $70.02 \pm 1.94^{a b}$ & $43.46 \pm 1.45^{\mathrm{ab}}$ & $6.07 \pm 0.18$ & $11.27 \pm 0.81^{\mathrm{ab}}$ \\
\hline Cellulase & $87.91 \pm 1.60$ & $4.76 \pm 0.58^{\mathrm{a}}$ & $2.21 \pm 0.17$ & $69.01 \pm 1.27^{b}$ & $41.58 \pm 1.68^{c}$ & $6.09 \pm 0.17$ & $11.76 \pm 1.34^{\mathrm{a}}$ \\
\hline LAB+cellulase & $88.07 \pm 1.04$ & $4.63 \pm 0.53^{\mathrm{ab}}$ & $2.17 \pm 0.19$ & $69.16 \pm 0.91^{b}$ & $41.80 \pm 1.99^{\mathrm{bc}}$ & $6.09 \pm 0.17$ & $11.71 \pm 1.06^{\mathrm{a}}$ \\
\hline \multicolumn{8}{|c|}{ Significance of main effects and interactions } \\
\hline Sealing (S) & 0.07 & $<0.01$ & 0.09 & $<0.01$ & $<0.01$ & 0.61 & 0.47 \\
\hline Additive (A) & 0.43 & 0.17 & 0.43 & 0.03 & 0.03 & 0.87 & 0.11 \\
\hline$S \times A$ & 0.67 & 0.12 & 0.86 & 0.29 & 0.81 & 0.99 & 0.32 \\
\hline
\end{tabular}

Data are means of three silage samples.

OM, organic matter; $C P$, crude protein; EE, ether extract; NDF, neutral detergent fiber; ADF, acid detergent fiber; ADL, acid detergent lignin; NFC, non-fibrous carbohydrate. DM, dry matter; LAB, lactic acid bacteria inoculant Chikuso-1; SEM, standard error of the mean.

${ }^{\text {a.c }}$ Means \pm standard deviation within columns with different superscript letters differ significantly from each other $(p<0.05)$.

trated that respiration within hydrated plant tissues continues after mowing. According to such previous studies, the effects of DS on pre-ensiled forage result in wetting, which increases the water activity and proteolysis (as moisture stimulates plant and bacterial proteolytic enzymes), and reduces the WSC, CP, and NDF contents (due to the long aerobic exposure and the vigorous growth of epiphytic microbes). However, rainfall before ensiling may increase the moisture of DS forage, and thus the DM of DS could be similar to that of QS.

To better understand the microbial populations in Napier grass, we investigated the abundances of four kinds of microbes: LAB, aerobic bacteria, molds, and yeasts. Epiphytic $\mathrm{LAB}$ are naturally present in forage crops, and they are responsible for silage fermentation [12,22]. In this study, aerobic bacteria dominated the microbial populations in QS and DS. LAB were present on QS and DS in low numbers, which could not produce sufficient lactic acid during fermentation to reduce the $\mathrm{pH}$ and inhibit the growth of clostridia; therefore, the fermentation quality of the silage was poor. In this case, bacterial inoculants would be necessary to control the contaminating microbes during silage fermentation.

The addition of cellulase potentially increases the WSC substrate for $\mathrm{LAB}$ and thus may be a practical tool for enhancing silage fermentation [10]. In the present study, the contents of NDF and ADF were lower in cellulase-treated QS silages. Generally, cellulases catalyze the hydrolysis of cellulose (mainly endoglucanases, cellobiohydrolases, and $\beta$-glucosidases), and any mixture or complex of such enzymes that acts serially or synergistically can be used to decompose cellulosic material. The cellulases produced by Acremonium cellulolyticus, which were used in this study, contain glucanase and pectinase, indicating that this cellulase should be effective for cellulose degradation. However, the LAB or cellulase addition had no effect on the chemical composition of the DS silage. The reason may be that the abnormal growth of harmful microbes consumed sugars in the DS process, which hindered LAB growth and enzyme activity during subsequent ensiling. The microbial additive also had no significant effect on silage fermentation with the DS material.

Some epiphytic LAB, such as lactobacilli, can grow well at low $\mathrm{pH}$ and produce more lactic acid in the silage environment, which alters the microorganism community and silage fermentation $[10,23]$. In this study, there was a very low epiphytic LAB count on forage, and lactic acid-producing cocci 
Table 4. Fermentation quality of Napier grass silage after $60 \mathrm{~d}$ of fermentation

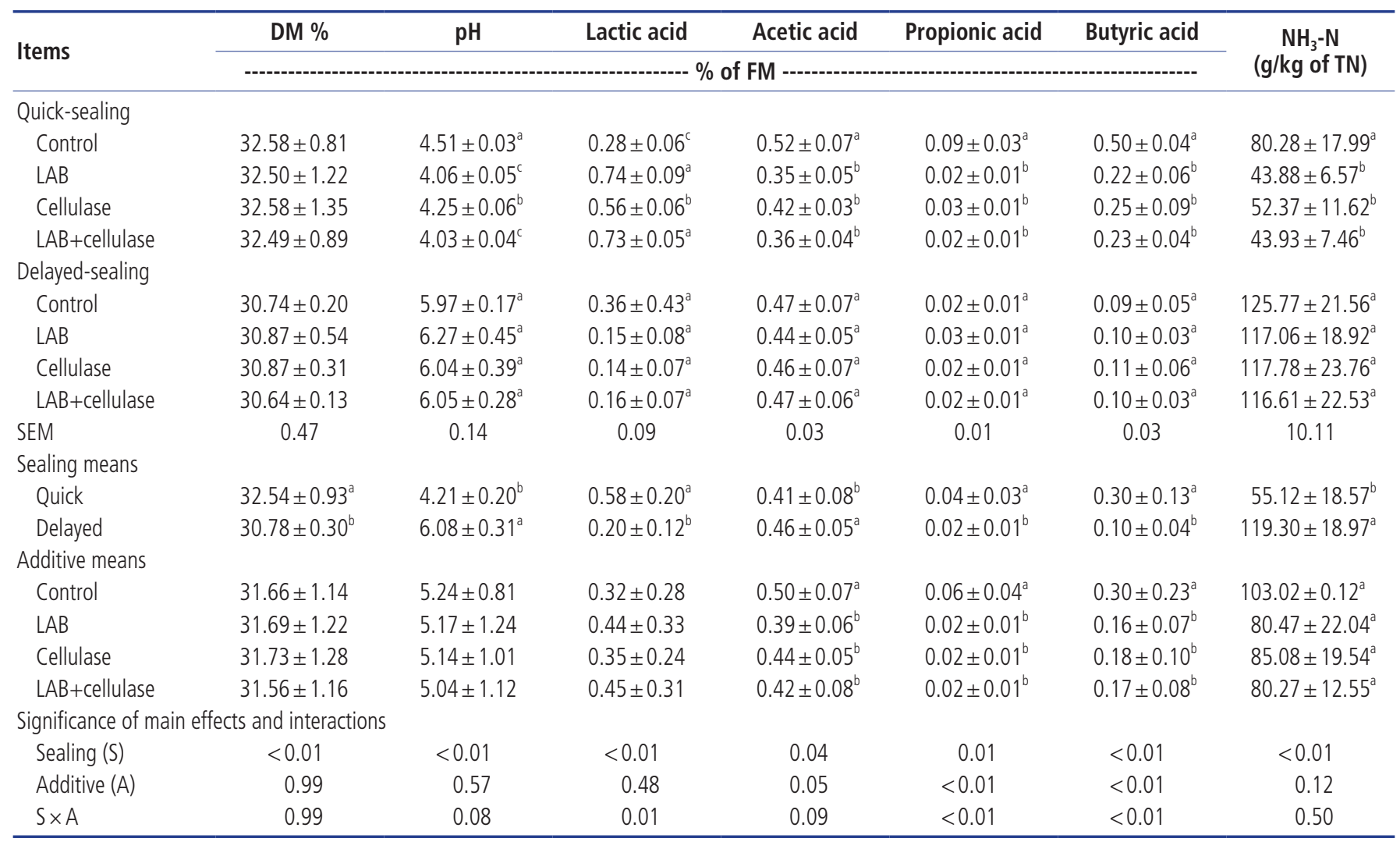

Data are means of three silage samples.

$\mathrm{DM}$, dry matter; $\mathrm{FM}$, fresh matter; $\mathrm{NH}_{3}-\mathrm{N}$, ammonia nitrogen; $\mathrm{TN}$, total nitrogen; $\mathrm{LAB}$, lactic acid bacteria inoculant Chikuso-1; SEM, standard error of the mean.

a-c Means \pm standard deviation within columns with different superscript letters differ significantly from each other $(p<0.05)$.

were the main population. This is one reason why it was impossible to produce high-quality silage. Coccid LAB cannot grow long enough to produce sufficient lactic acid in a low$\mathrm{pH}$ environment. When the $\mathrm{pH}$ of silage was higher than 4.20 ,

Table 5. Microbial populations of Napier grass silage after $60 \mathrm{~d}$ of fermentation

\begin{tabular}{|c|c|c|c|c|c|}
\hline \multirow{2}{*}{ Items } & Lactic acid bacteria & Coliform bacteria & Aerobic bacteria & Yeast & Mold \\
\hline & \multicolumn{5}{|c|}{ - } \\
\hline \multicolumn{6}{|l|}{ Quick-sealing } \\
\hline Control & $5.47 \pm 0.56^{b}$ & $3.71 \pm 1.13^{\mathrm{a}}$ & $4.49 \pm 1.02$ & $5.00 \pm 0.41$ & $0.63 \pm 1.10^{a}$ \\
\hline$L A B$ & $5.99 \pm 0.43^{\mathrm{ab}}$ & ND & $4.37 \pm 0.45$ & $4.05 \pm 0.61$ & ND \\
\hline Cellulase & $6.70 \pm 0.20^{\mathrm{a}}$ & ND & $4.19 \pm 0.75$ & $3.97 \pm 0.29$ & ND \\
\hline LAB+cellulase & $6.03 \pm 0.70^{\mathrm{ab}}$ & ND & $5.13 \pm 0.36$ & $4.31 \pm 0.79$ & ND \\
\hline \multicolumn{6}{|l|}{ Delayed-sealing } \\
\hline Control & $5.03 \pm 0.62^{\mathrm{a}}$ & $5.22 \pm 0.58^{\mathrm{a}}$ & $6.32 \pm 0.58$ & $5.87 \pm 0.39$ & $4.64 \pm 0.38^{a}$ \\
\hline$L A B$ & $5.63 \pm 0.17^{a}$ & $5.40 \pm 0.61^{\mathrm{a}}$ & $6.38 \pm 0.48$ & $6.16 \pm 0.73$ & $5.20 \pm 0.56^{a}$ \\
\hline Cellulase & $5.36 \pm 0.37^{\mathrm{a}}$ & $5.32 \pm 0.52^{\mathrm{a}}$ & $6.26 \pm 0.34$ & $5.96 \pm 0.76$ & $4.78 \pm 0.49^{a}$ \\
\hline LAB+cellulase & $5.25 \pm 0.92^{\mathrm{a}}$ & $5.37 \pm 0.50^{\mathrm{a}}$ & $6.19 \pm 0.71$ & $5.96 \pm 0.48$ & $4.73 \pm 0.55^{\mathrm{a}}$ \\
\hline SEM & 0.32 & 0.32 & 0.36 & 0.34 & 0.30 \\
\hline \multicolumn{6}{|c|}{ Significance of main effects and interactions } \\
\hline Sealing (S) & $<0.01$ & $<0.01$ & $<0.01$ & $<0.01$ & $<0.01$ \\
\hline Additive (A) & 0.13 & $<0.01$ & 0.69 & 0.56 & 0.73 \\
\hline$S \times A$ & 0.44 & $<0.01$ & 0.49 & 0.29 & 0.30 \\
\hline
\end{tabular}

Data are means of three silage samples.

cfu, colony-forming unit; FM, fresh matter; LAB, lactic acid bacteria inoculant Chikuso-1; ND, not detected; SEM, standard error of the mean.

a,b Means \pm standard deviation within columns with different superscript letters differ significantly from each other $(p<0.05)$. 
Table 6. Changes in lactic acid content, yeast and mold counts, pH and temperature during aerobic exposure of bunker silage for 1, 3, and $6 \mathrm{~d}$

\begin{tabular}{|c|c|c|c|c|c|}
\hline \multirow{2}{*}{ Items } & \multirow{2}{*}{ Lactic acid ( $\%$ of FM) } & \multicolumn{2}{|c|}{ Microbial population ( $\log _{10}$ cfu/g of FM) } & \multirow{2}{*}{$\mathrm{pH}$} & \multirow{2}{*}{ Temperature $\left({ }^{\circ} \mathrm{C}\right)$} \\
\hline & & Yeast & Mold & & \\
\hline \multicolumn{6}{|l|}{ Quick-sealing } \\
\hline $1 d$ & $0.52 \pm 0.05^{\mathrm{a}}$ & $4.59 \pm 0.38^{\mathrm{a}}$ & ND & $4.86 \pm 0.38^{\mathrm{a}}$ & $27.21 \pm 0.38^{b}$ \\
\hline $3 d$ & $0.42 \pm 0.04^{\mathrm{a}}$ & $5.84 \pm 0.89^{\mathrm{a}}$ & ND & $5.26 \pm 0.27^{\mathrm{a}}$ & $27.74 \pm 0.50^{b}$ \\
\hline $6 d$ & $0.11 \pm 0.06^{b}$ & $5.84 \pm 0.89^{\mathrm{a}}$ & $3.80 \pm 0.23^{\mathrm{a}}$ & $5.45 \pm 0.35^{\mathrm{a}}$ & $30.35 \pm 1.01^{\mathrm{a}}$ \\
\hline \multicolumn{6}{|l|}{ Delayed-sealing } \\
\hline $1 d$ & $0.05 \pm 0.08^{\mathrm{a}}$ & $7.46 \pm 0.74^{b}$ & $4.13 \pm 0.50^{c}$ & $6.30 \pm 0.85^{b}$ & $34.20 \pm 1.30^{b}$ \\
\hline $3 d$ & ND & $8.48 \pm 0.18^{\mathrm{a}}$ & $5.30 \pm 0.39^{b}$ & $6.80 \pm 0.35^{\mathrm{ab}}$ & $38.30 \pm 0.44^{\mathrm{a}}$ \\
\hline $6 d$ & ND & $9.43 \pm 0.43^{\mathrm{a}}$ & $6.93 \pm 0.74^{\mathrm{a}}$ & $7.36 \pm 0.25^{\mathrm{a}}$ & $35.14 \pm 0.34^{b}$ \\
\hline SEM & 0.03 & 0.37 & 0.24 & 0.19 & 0.44 \\
\hline \multicolumn{6}{|c|}{ Significance of main effects and interactions } \\
\hline Sealing $(S)$ & $<0.01$ & $<0.01$ & $<0.01$ & $<0.01$ & $<0.01$ \\
\hline Exposure d (D) & $<0.01$ & $<0.01$ & $<0.01$ & $<0.01$ & $<0.01$ \\
\hline$S \times D$ & $<0.01$ & 0.44 & $<0.01$ & 0.44 & $<0.01$ \\
\hline
\end{tabular}

Data are means of three silage samples.

cfu, colony-forming unit; FM, fresh matter; ND, not detected; SEM, standard error of the mean.

${ }^{a-c}$ Means \pm standard deviation within columns with different superscript letters differ significantly from each other $(p<0.05)$.

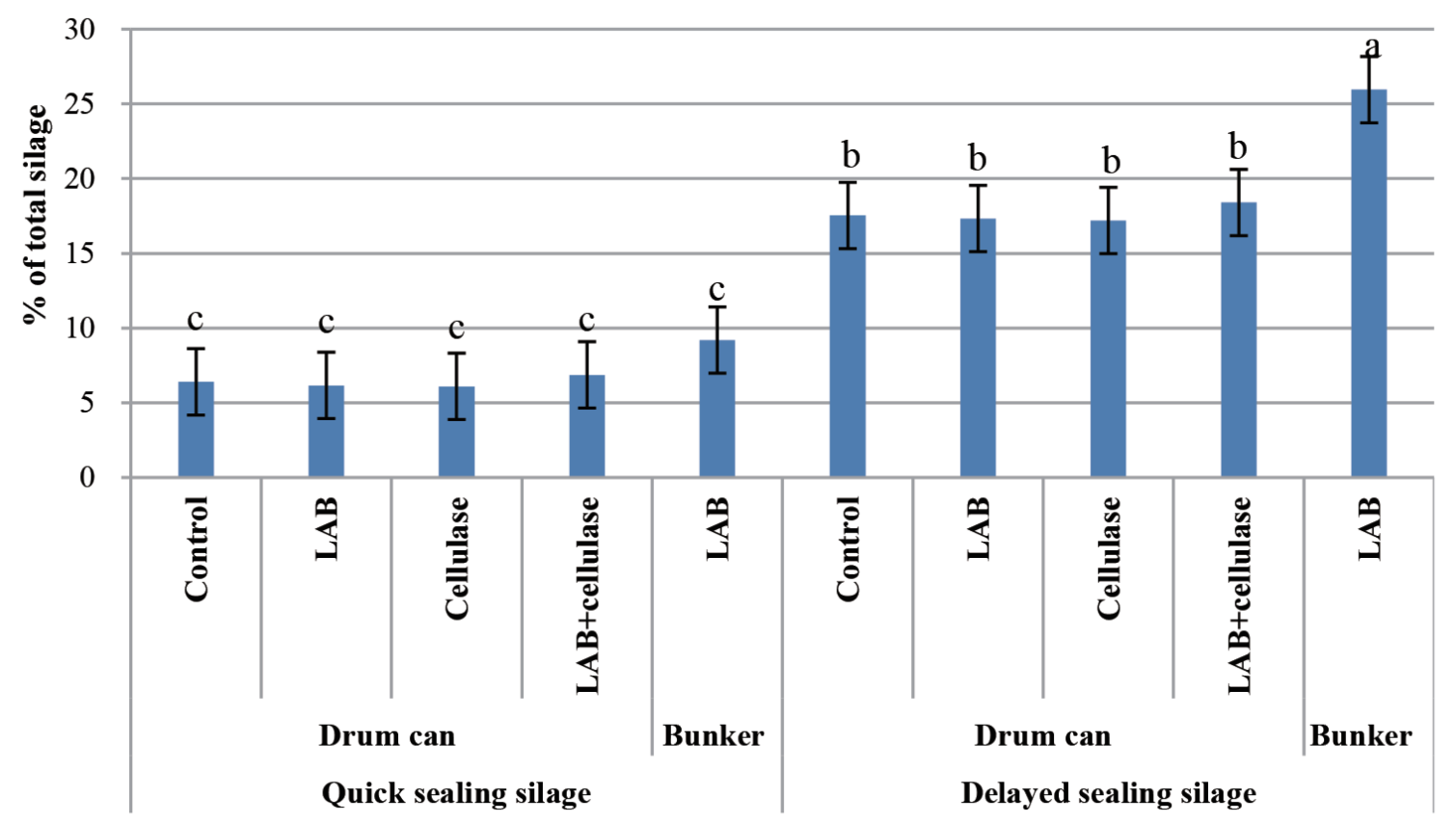

Figure 1. Spoilage loss of quick-sealing and delayed-sealing silage prepared with drum can and bunker silo. Data are means of three silage samples. $L A B$, lactic acid bacteria inoculant Chikuso-1. ${ }^{a-c}$ Means \pm standard deviation within all the treatments with different superscript letters differ significantly from each other $(p<0.05)$.

the growth of clostridia was not inhibited, and butyric acid fermentation occurred. The microbial additive-treated QS Napier grass silage was of better quality than the control. Cellulase can degrade fiber, thus increasing sugar content, which can be used as a fermentation substrate by LAB. The inoculant used in this study was a homofermentative LAB, which grew well under low $\mathrm{pH}$ and had high lactic acid production capacity [10]. However, all of the DS silages were of poor quality, and the microbial additive did not improve the fermentation quality of the silage. In the DS Napier grass silage, the DS and prolonged exposure to air in the pre-sealing phase allowed the development of a large population of aerobic bacteria and yeast. These aerobic microbes dominated the fermentation process, leading to fermentation failure and silage deterioration. The degradation of the WSC and the fermentation acids could be attributed to the intense metabolic activity of yeasts in the early stage and molds in the later stage. Therefore, the development of aerobic mi- 
croorganisms and the loss of WSC during the DS process greatly limited future silage fermentation by LAB, and a reduced delay time and QS were key to ensiling success in silage preparation.

Cai et al [10] reported that LAB improves fermentation quality but does not inhibit the growth of yeast and might increase the aerobic deterioration of silage. The deterioration of silage increases the DM loss from a silo and reduces the nutritional value of silage [10]. In addition, some aerobic microorganisms can be harmful to livestock. Therefore, preventing the aerobic deterioration of silage is very important $[6,9]$.

Usually, acid-tolerant yeasts can survive ensiling. Thus, when silage is exposed to air after opening a silo, rapid yeast proliferation can occur [24]. In the present study, the DS silage was more susceptible to aerobic exposure than the QS silage. The aerobic bacteria, yeast, and mold counts in the DS silage were high and increased during ensiling and aerobic exposure. These microorganisms are able to grow under high $\mathrm{pH}$ despite being in an anaerobic environment, and they can utilize lactic acid and WSC for growth. Aerobic bacteria, yeasts, and molds were found to grow vigorously after opening of the silo, leading to rapid aerobic deterioration and spoilage loss of DS silage. Therefore, good sealing conditions not only improved silage fermentation but also reduced spoilage loss.

\section{CONCLUSION}

The effects of LAB inoculant and cellulase enzymes on microbial populations, ensiling characteristics, and aerobic deterioration of DS silage of Napier grass in Africa were investigated. Aerobic bacteria, yeasts, and molds grew vigorously during DS and increased during ensiling and aerobic exposure, causing poor fermentation and spoilage loss of Napier grass silage. The LAB and enzyme improved fermentation quality for QS silage but were not effective for DS silage of Napier grass.

\section{CONFLICT OF INTEREST}

We certify that there is no conflict of interest with any financial organization regarding the material discussed in the manuscript.

\section{ACKNOWLEDGMENTS}

This work was supported by the project "Development of Sustainable Technologies to Increase Agricultural Productivity and Improve Food Security in Africa (Food Security in Africa)", which was jointly conducted by Japan International Research Center for Agricultural Sciences (JIRCAS), Japan, and Agricultural Research Institute of Mozambique (IIAM), Mozambique. Forage samples imported from Mozambique to Japan based on the Material Transfer Agreement between JIRCAS and IIAM. The import certificate was permitted by the Minister of Agriculture, Forestry, and Fisheries of Japan under Act on Domestic Animal Infectious Diseases Control.

\section{REFERENCES}

1. Desta ST, Yuan X, Li J, Shao T. Ensiling characteristics, structural and nonstructural carbohydrate composition and enzymatic digestibility of Napier grass ensiled with additives. Bioresour Technol 2016;221:447-54. https://doi.org/10.1016/ j.biortech.2016.09.068

2. Gulfam A, Guo G, Tajebe S, et al. Characteristics of lactic acid bacteria isolates and their effect on the fermentation quality of Napier grass silage at three high temperatures. J Sci Food Agric 2017;97:1931-8. https://doi.org/10.1002/jsfa.7998

3. Woodard KR, Sollenberger LE. Production of biofuel crops in Florida: Elephant grass (SS-AGR-297). Gainesville, FL, USA: Agronomy Department, University of Florida (UF)/ Institute of Food and Agricultural Sciences (IFAS) Extension; 2008.

4. Hayashi Y, Devkota NR, Kumagai H. Effects of field pea (Pisum sativum L.) hay feeding on dry matter intake and milk production of Murrah buffaloes (Bubalus bubalis) fed rice straw ad libitum. Anim Sci J 2007;78:151-8. https:/doi. org/10.1111/j.1740-0929.2007.00419.x

5. Brown WH, Jareed AO, Stull JW. Comparison of milo and barley for lactating cows. II. Effects of roughage intake and season. J Dairy Sci 1967;50:700-4. https://doi.org/10.3168/ jds.S0022-0302(67)87496-4

6. Wiedmeier RD, Provenza FD, Burritt EA. Exposure to ammoniated wheat straw as suckling calves improves performance of mature beef cows wintered on ammoniated wheat straw. J Anim Sci 2002;80:2340-8. https://doi.org/10.1093/ansci/80. 9.2340

7. Brink G, Hall M, Shewmaker G, Undersander D, Martin N, Walgenbach $\mathrm{R}$. Changes in alfalfa yield and nutritive value within individual harvest periods. Agron J 2010;102:127482. https://doi.org/10.2134/agronj2010.0080

8. Fonnesbeck PV, Garcia De Hernandez MM, Kaykay JM, Saiady MY. Estimating yield and nutrient losses due to rainfall on field-drying alfalfa hay. Anim Feed Sci Technol 1986;16: 7-15. https://doi.org/10.1016/0377-8401(86)90045-3

9. Wilkinson JM, Davies DR. The aerobic stability of silage: key findings and recent developments. Grass Forage Sci 2013;68: 1-19. https://doi.org/10.1111/j.1365-2494.2012.00891.x

10. Cai Y, Benno Y, Ogawa M, Kumai S. Effect of applying lactic acid bacteria isolated from forage crops on fermentation characteristics and aerobic deterioration of silage. J Dairy Sci 1999;82:520-6. https://doi.org/10.3168/jds.S0022-0302 (99)75263-X

11.Kozaki M, Uchimura T, Okada S. Experimental manual for lactic acid bacteria. Asakurasyoten (in Japanese), Tokyo, Japan: 
Tosho Printing Co., Ltd.; 1992. p. 29-72.

12. Cai Y, Benno Y, Ogawa M, Ohmomo S, Kumai S, Nakase T. Influence of Lactobacillus spp. from an inoculant and of Weissella and Leuconostoc spp. from forage crops on silage fermentation. Appl Environ Microbiol 1998;64:2982-7.

13. Association of Official Agricultural Chemists (AOAC). Official methods of analysis. 17th ed. Arlington, VA, USA: Intertional Association of Official Analytical Chemists; 2000.

14. Van Soest PJ, Robertson JB, Lewis BA. Methods for dietary fiber, neutral detergent fiber, and nonstarch polysaccharides in relation to animal nutrition. J Dairy Sci 1991;74:3583-97. https://doi.org/10.3168/jds.S0022-0302(91)78551-2

15. Hall MB. Calculation of non-structural carbohydrate content of feeds that Contain non-protein nitrogen. Gainesville FL, USA: University of Florida; 2000.

16. McDonald P, Henderson AR, Heron SJE. The biochemistry of silage. Marlow, NH, USA: Chalcombe Publications; 1991. p. 1-340.

17. Cai Y. Analysis method for silage. In: Japanese Society of Grassland Science, Field and Laboratory Methods for Grassland Science. Tokyo, Japan: Tosho Printing Co., Ltd.; 2004. p. 27982.

18. Steel RGD, Torrie JH. Principles and procedure of statistics. New York, USA: McGraw-Hill Book Co., Inc.; 1980.

19. Khota W, Pholsen S, Higgs D, Cai Y. Natural lactic acid bac- teria population of tropical grasses and their fermentation factor analysis of silage prepared with cellulase and inoculant. J Dairy Sci 2016;99:9768-81. https://doi.org/10.3168/jds.201611180

20. Muck RE, Filya I, Contreras-Govea FE. Inoculant effects on alfalfa silage: in vitro gas and volatile fatty acid production. J Dairy Sci 2007;90:5115-25. https://doi.org/10.3168/jds.2006878

21. Coblentz WK, Muck RE. Effects of natural and simulated rainfall on indicators of ensilability and nutritive value for wilting alfalfa forages sampled before preservation as silage. J Dairy Sci 2012;95:6635-53. https://doi.org/10.3168/jds.20125672

22.Lin C, Bolsen KK, Brent BE, Hart RA, Dickerson JT. Epiphytic microflora on alfalfa and whole-plant corn. J Dairy Sci 1992; 75:2484-93. https://doi.org/10.3168/jds.S0022-0302(92)78 $010-2$

23. Ni K, Wang Y, Cai Y, Pang H. Natural lactic acid bacteria population and silage fermentation of whole-crop wheat. Asian-Australas J Anim Sci 2015;28:1123-32. https://doi. org/10.5713/ajas.14.0955

24. Pahlow G, Muck RE, Driehuis F, Oude Elferink SJWH, Spoelstra SF. Microbiology of ensiling. In: Buxton DR, Muck RE, Harrison JH, editors. Madison, USA: Silage Science and Technology; 2003. p. 31-93. 